\title{
APLICAÇÃO DE DESSECANTES EM PRÉ-COLHEITA: EFEITO NA QUALIDADE FISIOLÓGICA DE SEMENTES DE SOJA ${ }^{1}$
}

\author{
ELIANE MARIA FORTE DALTRO²; MARIA CRISTINA DE FIGUEIREDO E ALBUQUERQUE; \\ JOSÉ DE BARROS FRANÇA NETO4; SEBASTIÃO CARNEIRO GUIMARÃES; \\ DIONÍSIO LUIIZ PIZA GAZZIERO4; ADEMIR ASSIS HENNING ${ }^{4}$
}

\begin{abstract}
RESUMO - Oscilações de temperatura acompanhadas de altos índices pluviais e flutuação de umidade relativa do ar, nas fases de maturação e pré-colheita, podem provocar perdas na qualidade física, fisiológica e na sanidade de sementes. A aplicação de dessecantes em pré-colheita contribui para a redução da exposição das sementes a condições climáticas desfavoráveis e para diminuir a possibilidade de prejuízos à germinação e vigor. Nesta pesquisa o objetivo foi avaliar o efeito da época de aplicação de dessecantes e da antecipação da colheita sobre a qualidade fisiológica de sementes de soja. Os experimentos foram conduzidos com as cultivares MG/BR-46 Conquista e FMT Tucunaré, na safra 2005/2006, e BRS MT Pintado e FMT Tucunaré, na safra 2006/2007, em Alto Garças, MT. Utilizou-se delineamento experimental blocos casualizado, em esquema fatorial $6 \times 2 \times 2 \times 2$ (5 tratamentos dessecantes +1 testemunha, 2 épocas de dessecação, 2 épocas de colheita e 2 períodos de armazenamento). Os tratamentos dessecantes (paraquat, diquat, paraquat+diquat, paraquat+diuron e glifosato) foram aplicados nos estádios reprodutivos R6.5 e R7 e as sementes colhidas quando atingiram grau de umidade entre $17 \%$ e $20 \%$ (colheita antecipada) e entre $12 \%$ e $13 \%$ (colheita normal). As sementes obtidas em colheitas antecipadas foram submetidas à secagem em estufa com circulação forçada de ar, a $38^{\circ} \mathrm{C}-40{ }^{\circ} \mathrm{C}$, até atingirem graus de umidade entre $12 \%$ e $12,5 \%$. O desempenho das sementes foi avaliado em testes de germinação, classificação do vigor de plântulas, tetrazólio, emergência de plântulas em campo e comprimento de plântulas. Os dessecantes paraquat, diquat, paraquat+diquat e paraquat+diuron não influenciam a qualidade fisiológica das sementes, enquanto o glifosato provoca danos por fitotoxicidade no sistema radicular de plântulas de soja, afetando negativamente o desempenho da semente. A dessecação realizada nos estádios R6.5 ou R7, com exceção do uso do glifosato, possibilita a produção de sementes com desempenho semelhante. A colheita antecipada proporciona sementes de soja com melhor qualidade fisiológica.
\end{abstract}

Termos para indexação: Glycine max, maturidade fisiológica, glifosato, germinação, vigor.

\section{PRE-HARVEST DESICCATION: EFFECTS ON THE PHYSIOLOGICAL QUALITY OF SOYBEAN SEED}

\begin{abstract}
Temperature fluctuations associated with high rainfall and the oscillating relative humidity of the air during the pre-harvest stages of seed maturation may result in losses in physical and physiological quality and also in seed health. Pre-harvest desiccant application helps to reduces seed exposure to unfavourable climate conditions and reduce seed vigor and germination. The object of this research was to determine the effects of the application period of desiccants and of early harvesting on soybean seed quality. The experiments were conducted in Alto Garças, MT, with the
\end{abstract}

${ }^{1}$ Submetido em 10/07/2009. Aceito para publicação em 26/11/2009.Parte da Tese de Doutorado do primeiro autor apresentada à UFMT/FAMEV.

${ }^{2}$ Eng. Agr., Dra, Pesquisadora da EMPAER/MT, Rua Jarí Gomes, 454, Bairro Boa Esperança, CEP 78058-250, Cuiabá, MT, elianedaltro@gmail.com
${ }^{3}$ Eng. Agr., Dr., Prof. da Universidade Federal de Mato Grosso - UFMT, FAMEV, CEP 78060-900, Cuiabá, MT.

${ }^{4}$ Eng. Agr., Ph.D., Pesquisador da Embrapa Soja, Caixa Postal 231, CEP 86001-970, Londrina, PR. 
cultivars MG/BR-46 Conquista and FMT Tucunaré in the 2005/2006 growing season, and with BRS MT Pintado and FMT Tucunaré in 2006/2007. The experimental design was a randomized block in a factorial arrangement $6 \times 2 \times 2 \times 2$ [6 treatments (5 desiccants and 1 control), 2 application times, 2 harvest times and 2 storage periods]. Five desiccant treatments were evaluated: paraquat, diquat, paraquat + diquat, paraquat + diuron and glyphosate, applied at the R6.5 and R7 growing stages, which were compared to a control treatment. Seeds were harvested at two stages: first, when moisture content reached $17 \%$ to $20 \%$ (early harvest), and secondly, $12 \%$ to $13 \%$ (normal harvest). Seeds from early harvesting were dried to $12 \%$ to $12.5 \%$ moisture content in a forced air chamber at temperatures ranging from $38^{\circ} \mathrm{C}$ to $40^{\circ} \mathrm{C}$. Seed quality was evaluated by the following tests: germination, seedling vigor classification, tetrazolium, field seedling emergence and seedling growth. Paraquat, diquat, paraquat + diquat and paraquat + diuron as pre-harvest desiccants do not affect seed physiological quality but glyphosate causes phytotoxic damage to seedling roots. With the exception of glyphosate, pre-harvest desiccation at the R6.5 and R7 growth stages results in the production of seeds having a similar quality. Early harvest results in the production of higher quality seeds compared to those from a normal harvest.

Index terms: Glycine max, physiological maturity, glyphosate, germination, vigor.

\section{INTRODUÇÃO}

O principal problema na produção de sementes de soja é a deterioração por "umidade", dano progressivo e mais acentuado entre os demais danos associados a essas, como os danos por insetos, patógenos e o mecânico (França-Neto et al., 2007). A semente de soja é altamente higroscópica, absorve facilmente a água do ambiente, tendo seu grau de umidade dependente das oscilações do meio (França-Neto e Henning, 1984). As lesões causadas pelas expansões e contrações do tegumento, após uma série de ciclos de umedecimento e secagem, acentuam a sua fragilidade, reduzindo a proteção à semente e causando prejuízos ao seu desempenho (FrançaNeto e Henning, 1984).

O potencial de conservação de sementes de soja depende diretamente da qualidade fisiológica das mesmas no início do período de armazenamento, sendo intimamente relacionada ao momento da colheita (Lacerda et al., 2003). A semente encerra genes que expressam o potencial produtivo da cultivar, uma vez que a qualidade superior implica numa série de características economicamente desejáveis como, sanidade, adaptação às condições adversas de clima e solo, assim como maior capacidade de germinação (Costa et al., 2003).

Dessa forma, todos os procedimentos que possam contribuir para a preservação da qualidade fisiológica das sementes são benéficos, dentre eles a antecipação da colheita, tendo como uma das alternativas o uso de dessecantes. A prática da dessecação para minimizar os problemas do retardamento da colheita tem sido observada em diversas culturas (Miguel, 2003; Lacerda et al., 2005), com vantagens adicionais como a possibilidade de planejamento da colheita, maior eficiência das máquinas, controle de plantas daninhas que prejudicam o processo de colheita e redução dos danos oriundos de pragas e fungos que possam atacar a cultura no final do ciclo (Marcos Filho, 2005).

Diversos resultados positivos têm sido obtidos em relação à eficácia de dessecantes quanto à redução do grau de umidade e preservação da qualidade de sementes de soja (Durigan, 1980; Lacerda et al., 2003; Pelúzio et al., 2008; Kappes et al., 2009), entre outros. Entretanto, alguns aspectos importantes devem ser considerados quando se pretende usar dessecantes químicos, como o modo de ação do produto, as condições ambientais em que esse é aplicado, o estádio fenológico em que a cultura encontra-se, a eventual ocorrência de resíduos tóxicos no material colhido, a influência na produção, germinação e vigor de sementes (Lacerda et al., 2005).

O objetivo desta pesquisa foi verificar os efeitos de diferentes dessecantes aplicados em pré-colheita e da colheita antecipada sobre a qualidade fisiológica de sementes de soja.

\section{MATERIAL E MÉTODOS}

Os experimentos foram conduzidos na Fazenda Adriana, Alto Garças, Mato Grosso (latitude: $16^{\circ} 49^{\prime} 37^{\prime \prime}$ e longitude: $53^{\circ} 49^{\prime} 46^{\prime \prime}$; altitude: $810 \mathrm{~m}$ ), em Latossolo 
Vermelho Distrófico (cultivar Conquista) e Areias Quartizosas (cultivares Tucunaré, nas duas safras, e Pintado), apresentando temperatura e umidade relativa do ar médias de $26{ }^{\circ} \mathrm{C}$ e $64 \%$, respectivamente, no mês de fevereiro, período de maturação e colheita das sementes.

Foram implantados quatro experimentos, em campos para produção de sementes, dois na safra 2005/2006, com as cultivares MG/BR 46 - Conquista e FMT Tucunaré (ambas de ciclo precoce), e dois na safra 2006/2007, com as cultivares BRS FMT Pintado (ciclo médio) e FMT Tucunaré (ciclo precoce).

Utilizou-se delineamento experimental blocos casualizados, com quatro repetições, em esquema fatorial 6 x 2 × 2 × 2 (cinco tratamentos dessecantes +uma testemunha, duas épocas de dessecação, duas épocas de colheita e dois períodos de armazenamento), para cada cultivar, nos dois anos experimentais.

As especificações dos tratamentos dessecantes empregados nos experimentos encontram-se na Tabela 1. As dessecações foram realizadas com aplicador costal, pressurizado a $\mathrm{CO}_{2}$, com vazão de $250 \mathrm{~L} / \mathrm{ha}$, em plantas de soja nos estádios de maturação R6.5 (sementes totalmente formadas, vagens $50 \%$ amarelas e $50 \%$ verdes) e R7 (maturidade fisiológica: vagens, em sua maioria amarelas, com uma vagem totalmente madura na haste principal). A identificação dos estádios reprodutivos foi baseada em Fehr

TABELA 1. Especificação dos tratamentos dessecantes empregados nos experimentos.

\begin{tabular}{cccc}
\hline \multirow{2}{*}{ Nome Comum } & Nome Comercial & *Dosagem \\
\cline { 3 - 4 } & & Ingrediente Ativo $\left(\mathrm{g}\right.$ i.a.ha ${ }^{-1}$ ) & Produto Comercial L.ha $^{-1)}$ \\
\hline Paraquat & Gramoxone & 300 & 1,5 \\
Diquat & Reglone & 300 & 1,5 \\
Paraquat+Diquat & Gramoxone+Reglone & $150+150$ & $1,0+1,0$ \\
Paraquat+Diuron & Gramocil & 300 & 1,5 \\
Glifosato & Round up & $1.080^{* *}$ & 1,5 \\
\hline Testemunha & & Sem dessecação \\
\hline
\end{tabular}

*Foi adicionado o adjuvante Agral à calda de pulverização, na proporção de $0,1 \% \mathrm{v} / \mathrm{v}$, para todos os herbicidas dessecantes.

** $\left(\mathrm{g}\right.$ e.a.ha $\left.\mathrm{h}^{-1}\right)$

e Caviness (1977).

As sementes foram colhidas e trilhadas manualmente, quando atingiram grau de umidade entre $17 \%$ e $20 \%$ (colheita antecipada) e entre $12 \%$ e $13 \%$ (colheita normal). A produção de sementes foi calculada por parcela, sendo expressa em $\mathrm{kg} / \mathrm{ha}$. As sementes da colheita antecipada foram submetidas a secagem em estufa com circulação forçada de ar, com temperatura entre $38{ }^{\circ} \mathrm{C}$ e $40{ }^{\circ} \mathrm{C}$, até atingirem grau de umidade entre $12 \%$ e $12,5 \%$. A seguir, as sementes foram acondicionadas em caixas de papel e identificadas; parte das amostras foi utilizada para as análises iniciais da qualidade fisiológica e, o restante, armazenado por oito meses (fevereiro a outubro), nos dois anos experimentais, em unidade convencional da Semente Adriana, onde as condições de temperatura e umidade relativa do ar permaneceram em torno de $22{ }^{\circ} \mathrm{C}$ e $45 \%$, respectivamente. Após esse período foram realizadas novas avaliações da qualidade fisiológica.

Efetuaram-se as seguintes determinações: grau de umidade (Brasil, 1992); germinação (Brasil, 1992), após o tratamento das sementes com fungicida e com précondicionamento para reduzir a possibilidade da ocorrência de danos devido à sensibilidade à embebição rápida (FrançaNeto e Krzyzanowski, 1993); classificação do vigor de plântulas (Nakagawa, 1999); tetrazólio, com avaliação do vigor, da viabilidade e de danos por umidade - nível 3 a 8 (França-Neto et al., 1998); comprimento de plântulas e seus componentes (Nakagawa, 1999) e emergência de plântulas em campo (Nakagawa, 1999).

A análise estatística foi realizada separadamente para cada cultivar e época de semeadura. Os dados foram submetidos aos testes de Lilliefors (5\%), para verificar se os valores seguiram a distribuição normal, e de Cochran e Bartlett (5\%), para verificar a homogeneidade de variâncias. Os valores da variável dano por umidade, que não atenderam os requisitos de distribuição normal e de homogeneidade de variâncias, foram transformados para $\sqrt{ } \mathrm{x}+1$. Após a análise 
de variância, as médias foram comparadas pelo teste de Scott \& Knott a 5\% de probabilidade. Todas as análises foram realizadas com o programa computacional Sistema de Análise Estatística e Genética (SAEG 5.0).

\section{RESULTADOS E DISCUSSÃO}

Durante a condução dos experimentos de campo, a infecção das plantas de soja por ferrugem asiática (Phakopsora pachyrhizi), principalmente na safra 2006/2007, provocou o desfolhamento prematuro das plantas, ocasionando antecipações nas datas de colheita das sementes. Este fato prejudicou a condução dos ensaios naquela safra.

As dessecações, tendo como referência a data da semeadura, foram realizadas aos: 114 dias, (R6.5) e 117 dias (R7), em 'Conquista' e 116 dias (R6.5) e 118 dias (R7), em 'Tucunaré', ambas na safra 2005/2006; 112 dias (R6.5) e 117 dias (R7) em 'Tucunaré' e 118 dias (R6.5) e 120 dias (R7), em 'Pintado', estas duas na safra 2006/2007. As variações, em número de dias, para se atingir os estádios fenológicos R6.5 e R7 e para a realização das dessecações, foram decorrentes do ciclo de cada cultivar e das condições ambientais e sanitárias durante a condução de cada ano experimental.

Quanto à realização das colheitas, com exceção do glifosato que apresentou efeito mais lento na colheita antecipada, os demais tratamentos herbicidas não apresentaram diferença entre si quanto ao tempo de dessecação, sendo as colheitas realizadas no mesmo dia. No entanto, houve antecipação em torno de dois dias na colheita, em relação às testemunhas. Quanto à colheita normal, somente a cultivar Conquista apresentou antecipação de dois dias entre as parcelas dessecadas e as testemunhas, nas duas épocas de dessecação.

Resultados com antecipação de colheita de dois dias em relação à testemunha também foram obtidos por Kappes et al. (2009), analisando o potencial fisiológico de sementes de soja, cultivar M-Soy 8866, dessecadas com diquat e paraquat no município de Santa Carmem, norte de Mato Grosso, ano agrícola de 2006/2007. Verificaram que os lotes dessecados com paraquat apresentaram melhor desempenho em alguns dos testes de qualidade empregados, em relação à testemunha (sem dessecação).

Na Figura 1 têm-se os valores de precipitações pluviais computados em cada um dos quatro experimentos, nos períodos compreendidos entre as épocas de dessecação e a realização de cada colheita, e também, esses valores no período entre a colheita antecipada e a colheita normal, nas parcelas testemunhas. Os períodos compreendidos entre a colheita antecipada e a normal, nas sementes testemunhas e nas dessecadas (resultados médios entre os diferentes dessecantes), considerando os estádios R6.5 e R7 de dessecação, estão apresentados na Figura 2.

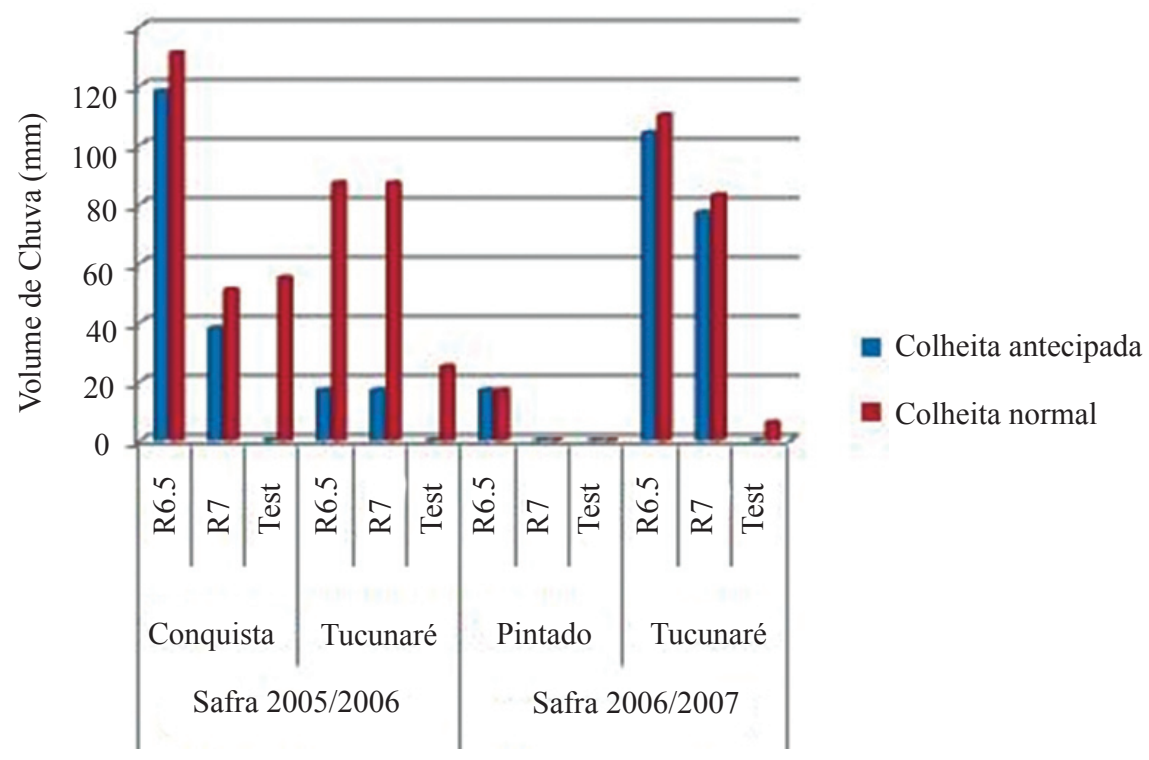

FIGURA 1. Precipitações pluviais $(\mathrm{mm})$ ocorridas nos experimentos, entre cada época de dessecação e as colheitas correspondentes e entre a colheita antecipada e a colheita normal nas parcelas testemunhas. 


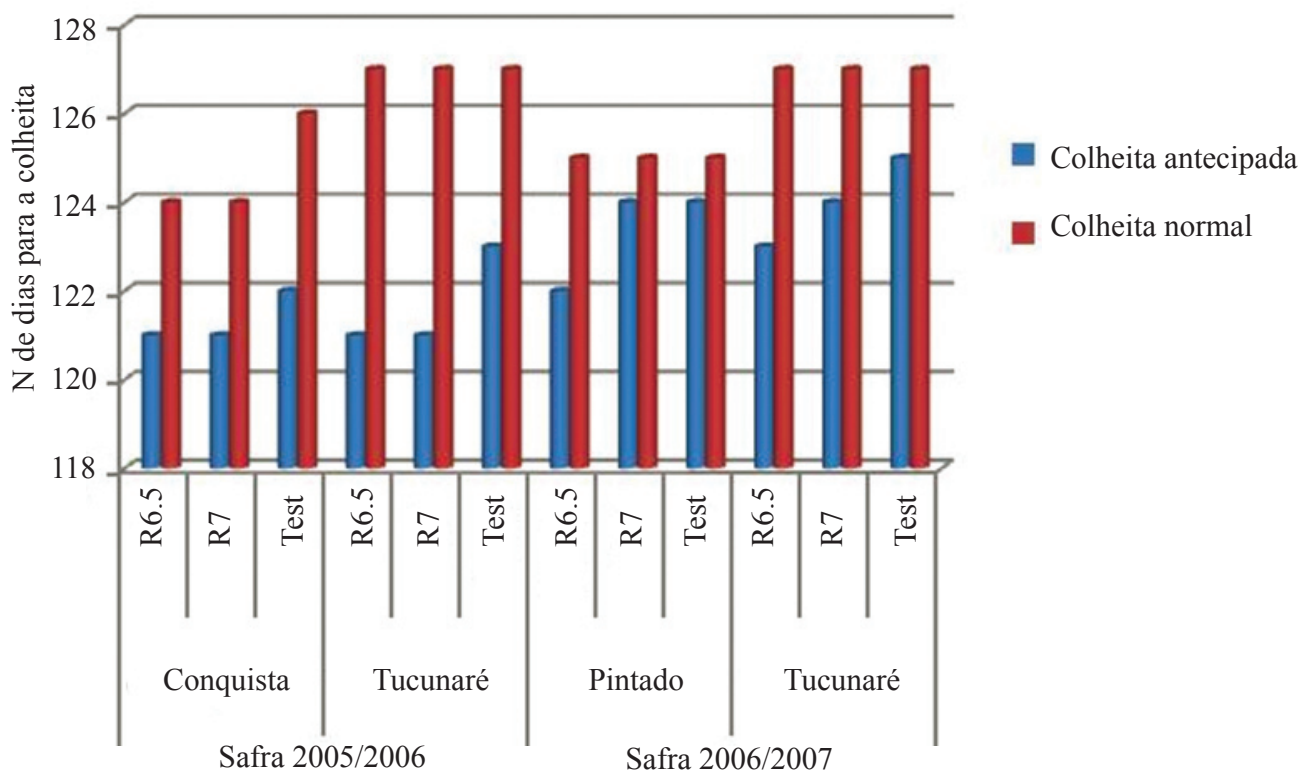

FIGURA 2. Períodos (dias) entre a semeadura e a colheita, influenciados por cultivares, ano agrícola, estádio de dessecação (média dos diferentes produtos) e grau de umidade das sementes (colheita antecipada e colheita normal).

Observa-se na Figura 1, com exceção do ensaio com a cultivar Pintado, safra 2006/2007, que houve ocorrência de chuvas no período entre a realização da colheita antecipada e a da colheita normal. Esses dados permitem inferir que, por menor que seja este período (Figura 2), nas condições do trópico úmido, a antecipação da colheita é favorável à manutenção do vigor e da viabilidade das sementes, evitando a exposição das mesmas a eventos climáticos, como à ocorrência de precipitações que são constantes na região nessa época do ano, o que contribui para o desencadeamento do processo de deterioração das sementes (Hamer, 1999).

Peske \& Hamer (1997) enfatizaram que, em condições de trópico úmido, o processo de secagem das sementes ainda no campo é rápido e a ocorrência de chuvas é frequente, ocasionando naquelas sementes já secas (12\% a 13\%), rápida deterioração. Há, assim, necessidade de realizar a colheita quando as sementes apresentam grau de umidade superior ao observado em regiões tradicionais de produção de sementes de soja. Esse procedimento viabiliza a obtenção de sementes de alta potencial fisiológico, em regiões de clima tropical úmido, porém requer controle mais cuidadoso dos processos de colheita e secagem.

Caseiro et al. (1997), estudando a antecipação de colheita pela avaliação do grau de umidade das sementes em cultivares de soja de maturação precoce, observaram que, devido à ocorrência de chuvas excessivas, a colheita a ser realizada com o grau de umidade inferior a $15 \%$ sofreu atraso de 14 dias em relação à última colheita realizada (entre $20 \%$ e $18 \%$ de água), devido à reidratação das sementes.

O rendimento das sementes variou de 3.000 a $3.800 \mathrm{~kg} /$ ha, não ocorrendo diferenças significativas entre os produtos dessecantes e entre esses e as testemunhas, dentro de cada cultivar analisada, como também entre as épocas de dessecação. Assim, pode-se afirmar que os produtos dessecantes utilizados, independentes do estádio em que foram aplicados, não interferiram no potencial produtivo das cultivares de soja. Provavelmente, deve-se ao período de aplicação dos dessecantes (R6.5 e R7), quando as sementes encontravam-se já formadas, no final da fase III (acúmulo de matéria seca) dos estádios de desenvolvimento das sementes (Dure, 1985; De Castro et al., 2004; Marcos Filho, 2005). Após a maturidade fisiológica, que representa também o fim do acúmulo de massa seca e do período de enchimento das sementes, essas perdem a conexão vascular com a planta-mãe.

O grau de umidade das sementes, nos quatro experimentos, variou significativamente durante o período de armazenamento. As mesmas apresentaram menor grau de umidade no final do período, devido às variações da temperatura e umidade relativa do ar no interior do armazém (França-Neto e Henning, 1984). Essas variações podem ter sido um dos principais fatores que interferiram na redução do potencial fisiológico das sementes, detectado de modo 
geral pelos testes realizados no final do armazenamento.

Durante as avaliações dos testes de germinação e de classificação do vigor de plântulas, para todas as cultivares, foi verificada uma anormalidade específica no sistema radicular, caracterizada pelo encurtamento da raiz principal e atrofiamento das raízes secundárias, nas plântulas originadas de sementes provenientes de plantas dessecadas com glifosato (Figura 3). Foram constatadas taxas médias de ocorrência desse sintoma de $17 \%$ para sementes de 'Conquista' e de 10\% para 'Tucunaré', ambas na safra $2005 / 2006$, e de $8 \%$ para 'Pintado' e de $16 \%$ para 'Tucunaré', na safra 2006/2007. Foi observado que a maior manifestação desse sintoma, com valores entre $60 \%$ e $65 \%$, ocorreu nas sementes provenientes da dessecação em R6.5. Essa anomalia pode ser atribuída à fitotoxicidade causada pelo referido herbicida.

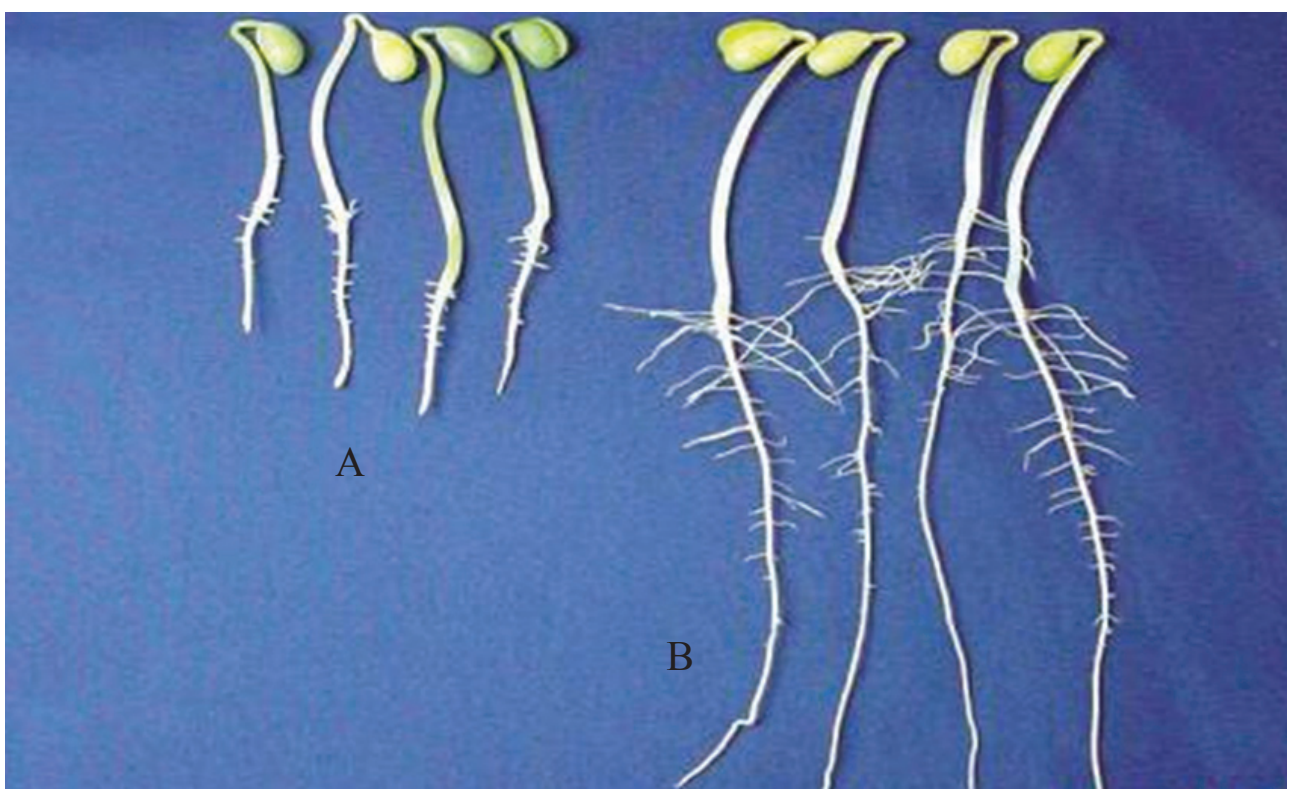

FIGURA 3. Comparação de plântulas anormais provenientes do tratamento glifosato (A) com plântulas normais do tratamento testemunha (B). Plântulas produzidas no teste de germinação. Foto: Odair Costa.

A fitotoxicidade é resultante de uma complexa interação entre o herbicida, a planta e as condições ambientais, sendo que seus efeitos podem ser muito variáveis. A fitotoxidez provocada por herbicida sistêmico (glifosato) normalmente é mais danosa, em comparação com a provocada por produtos de contato, pois o de contato destrói as plantas ou as partes sobre as quais é aplicado, porém não possui ação direta sobre raízes, bulbos, rizomas, etc; geralmente, sua ação é menos prolongada. O sistêmico é absorvido no local em que a gota foi interceptada, mas também exerce sua ação tóxica em outras partes da planta (Ferreira et al., 2007).

O efeito do herbicida glifosato sobre o sistema radicular das plântulas da cultivar Conquista 2005/2006, acarretou prejuízos ao desempenho, em relação aos demais dessecantes utilizados e à testemunha, manifestado na redução do poder germinativo e no vigor das plântulas (Figura 4). Resultados semelhantes foram obtidos por Villacorta (1980) em soja, que constatou que o glifosato provocou redução considerável da germinação de sementes e o vigor das plântulas, quando pulverizado em plantas com sementes fisiologicamente maduras ou em época próxima a essa.

Também, sementes da cultivar Tucunaré (2006/2007) procedentes de plantas dessecadas com glifosato, tanto em R6.5 quanto em R7 (Tabela 2), também apresentaram plântulas menos vigorosas em relação aos demais tratamentos, que não diferiram entre si. Quando comparadas as duas épocas de dessecação, foi observado também que não houve diferença entre os tratamentos, com exceção do glifosato que acarretou redução do potencial fisiológico, quando aplicado no estádio R6.5. Esses resultados foram semelhantes aos obtidos por Miguel (2003), que observou efeito variável do glifosato em sementes de feijão, de acordo com a época de aplicação. Esse produto afetou principalmente a germinação, quando a aplicação foi realizada antes das sementes atingirem o ponto de maturidade fisiológica, apresentando maior teor de água. 


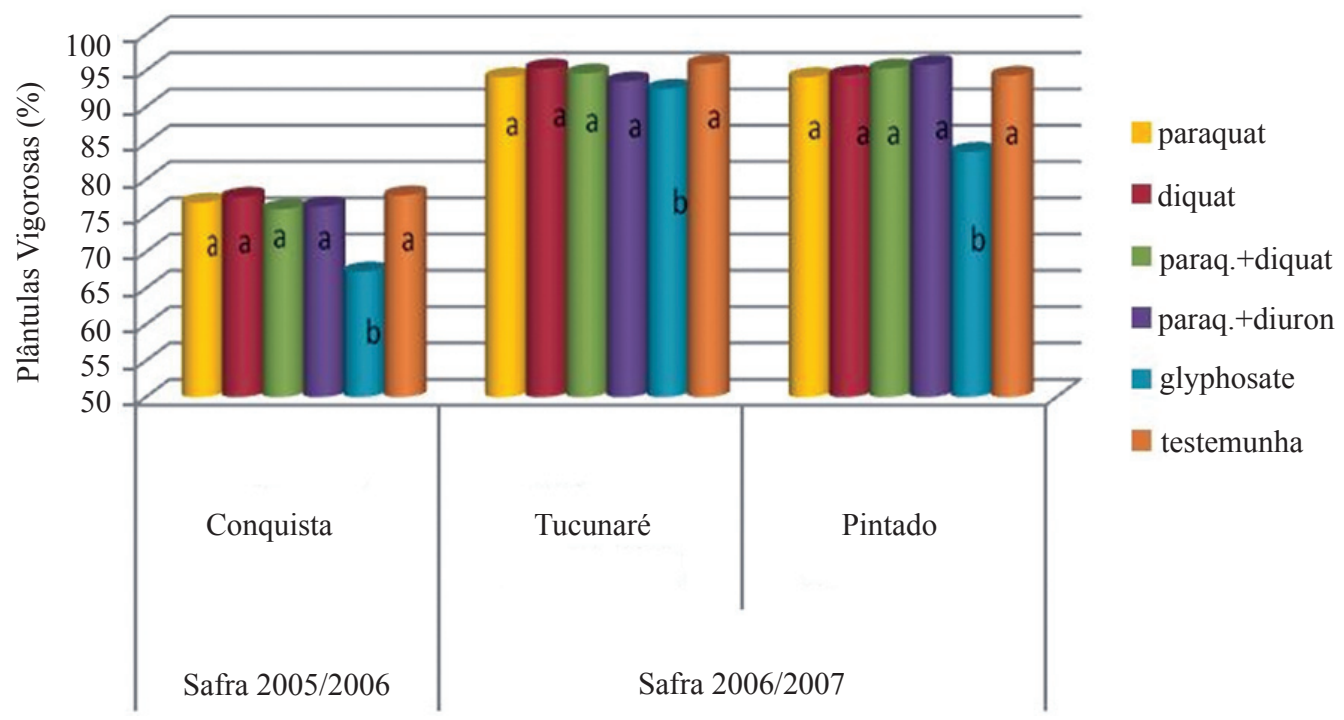

FIGURA 4. Resultados médios de plântulas vigorosas, para sementes oriundas de plantas dessecadas e testemunha, das cultivares Conquista, safra 2005/2006, Pintado e Tucunaré, safra 2006/2007.

TABELA 2. Resultados médios obtidos em testes de classificação do vigor de plântulas, referentes à interação "produto x época de dessecação", cultivar Tucunaré, safra 2006/2007.

\begin{tabular}{|c|c|c|c|}
\hline \multirow{3}{*}{ Produto } & \multicolumn{3}{|c|}{ Plântulas Vigorosas (\%) } \\
\hline & \multicolumn{2}{|c|}{ Dessecação } & \multirow{2}{*}{$\bar{X}$} \\
\hline & R6.5 & R7 & \\
\hline Paraquat & $94,7 \mathrm{a} \mathrm{A}$ & $93,4 \mathrm{a} \mathrm{A}$ & 94,1 \\
\hline Diquat & $94,4 \mathrm{a} A$ & $94,4 \mathrm{a} A$ & 94,4 \\
\hline Paraquat+Diquat & $95,0 \mathrm{a} A$ & $95,6 \mathrm{a} A$ & 95,3 \\
\hline Paraquat+Diuron & $96,5 \mathrm{a} A$ & $95,2 \mathrm{a} \mathrm{A}$ & 95,9 \\
\hline Glifosato & $78,3 \mathrm{~b} \mathrm{~B}$ & 89,4 b A & 83,9 \\
\hline Testemunha & $94,3 \mathrm{a} A$ & $94,3 \mathrm{a} A$ & 94,3 \\
\hline $\bar{X}$ & 92,2 & 93,7 & 93,0 \\
\hline $\mathrm{CV}(\%)$ & & & \\
\hline
\end{tabular}

Letras minúsculas comparam diferentes produtos em cada época de dessecação, e letras maiúsculas comparam cada produto entre as épocas de dessecação. Médias seguidas de mesma letra não diferem entre si (Scott-Knott 5\%).

O teste de emergência de plântulas em campo foi realizado somente no final do período de armazenamento, nas duas safras consecutivas. As sementes procedentes dos diversos tratamentos, produtos dessecantes, testemunhas, épocas de dessecação e épocas de colheita, apresentaram desempenho adequado. Porém, sementes dessecadas com glifosato apresentaram plântulas com sistemas radiculares atrofiados ou pouco desenvolvidas (Figura 5), confirmando resultados obtidos nos testes de germinação, quanto à ação fitotóxica desse herbicida.

No estudo do vigor e da viabilidade das sementes, determinados pelo teste de tetrazólio, verificou-se que as diferenças observadas não foram suficientes para destacar qualquer tratamento. Assim, pode-se afirmar que, nesse teste, não houve diferenças entre as épocas de dessecação, épocas de colheita, produtos dessecantes e entre estes e as 
testemunhas. As sementes correspondentes aos diferentes tratamentos e suas interações apresentaram vigor muito alto nesse teste, pois os valores superaram $85 \%$ (FrançaNeto et al., 1998) em todas as análises realizadas.

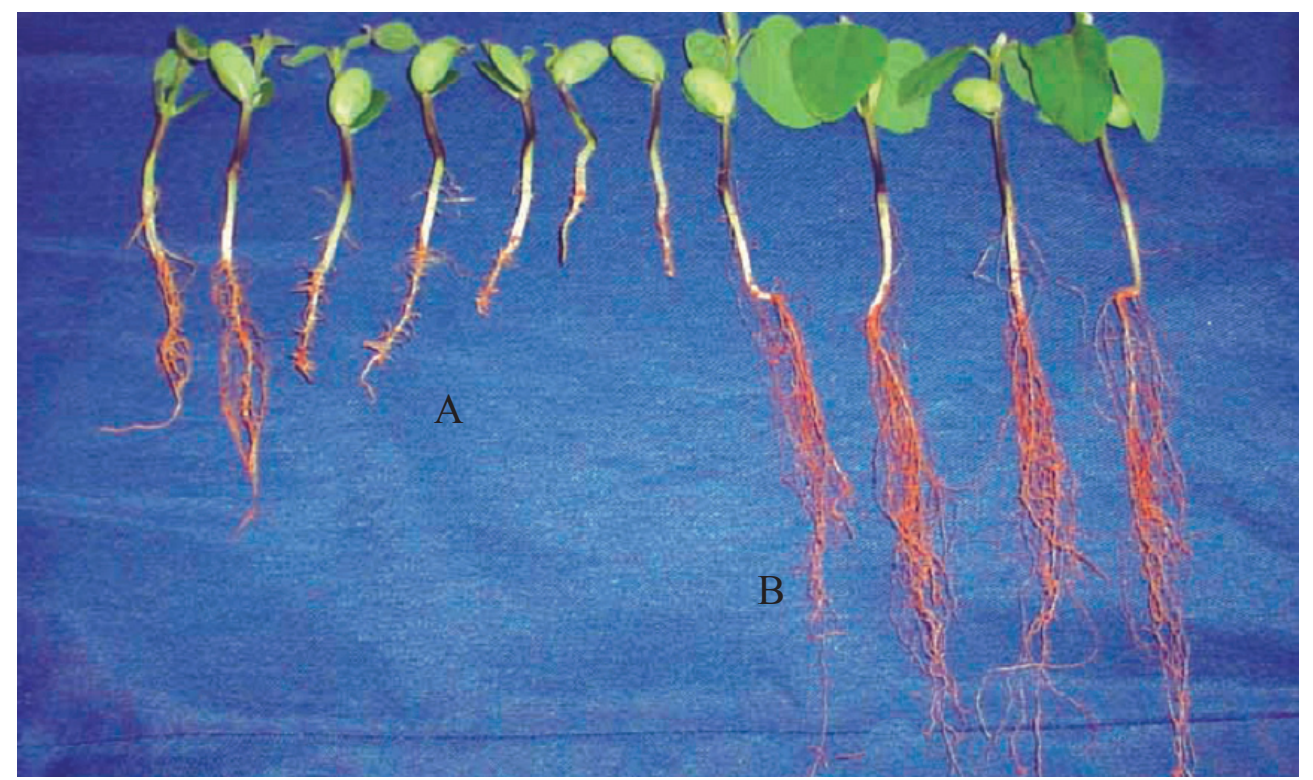

FIGURA 5. Comparação de plântulas de soja provenientes do tratamento glifosato (A) com plântulas do tratamento testemunha (B). Plântulas produzidas no teste de emergência em solo. Foto: Odair Costa.

Em contraste, na avaliação da deterioração por "umidade" (classes 3 a 8), no teste de tetrazólio, constataram-se diferenças significativas para períodos de armazenamento (Figura 6), com o aumento do dano por "umidade", para todas as cultivares, porém mais intenso na cultivar Tucunaré, safra 2005/2006. Além da exposição às chuvas na fase de pré-colheita (Figura 1), outros fatores degenerativos podem ter sido desencadeados e seus efeitos latentes manifestados durante o armazenamento.

Para França-Neto et al. (2007), o dano por "umidade" é um dos fatores que mais afetam o desempenho da semente de soja. Por essa razão, deve-se atentar para o período que antecede ao armazenamento, o qual poderá comprometer a viabilidade da semente durante o mesmo, uma vez que o nível de qualidade fisiológica da semente é definido no campo.

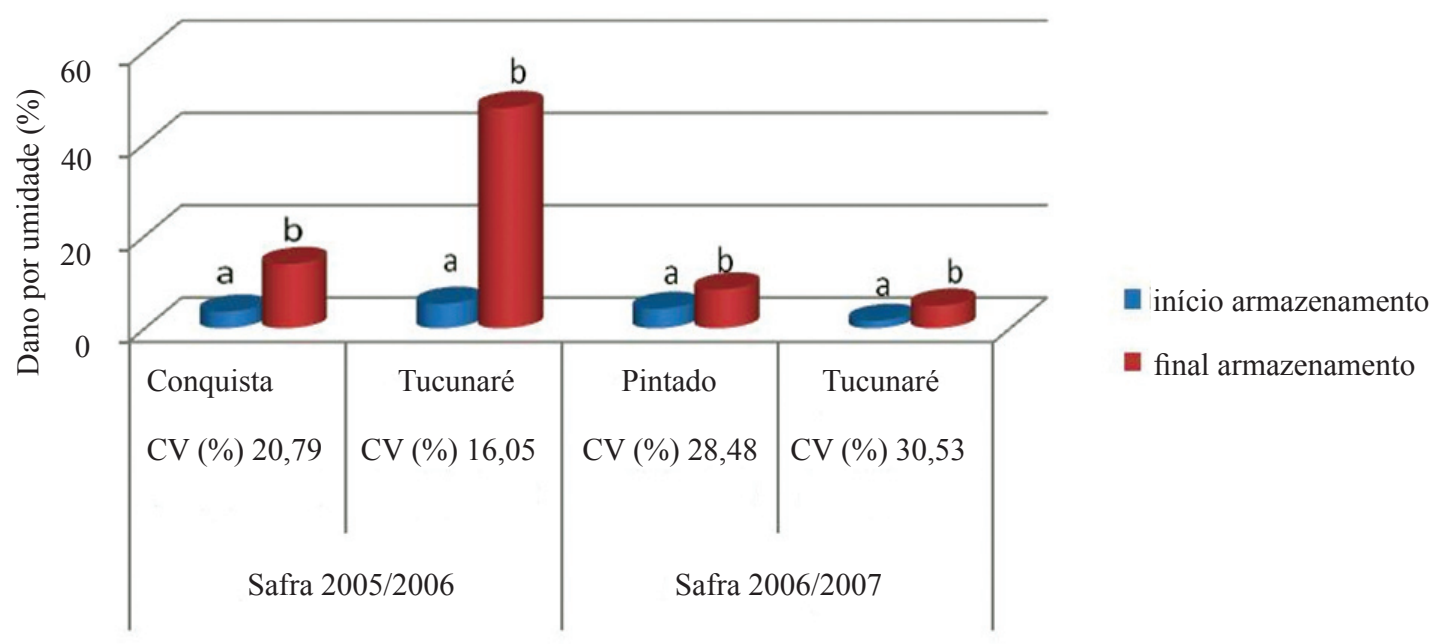

FIGURA 6. Resultados médios referentes a danos por "umidade" (classes 3 a 8), determinados em teste de tetrazólio, para as cultivares Conquista e Tucunaré, safra 2005/2006, e Pintado e Tucunaré, safra 2006/2007, no início e final do armazenamento. 
Não ocorreram diferenças estatísticas entre as épocas de dessecação nas duas safras estudadas, no que diz respeito aos danos por "umidade" na cultivar Tucunaré (Tabela 3). Com relação às épocas de colheita, tanto em 2005/2006 como em 2006/2007, as sementes provenientes da colheita antecipada apresentaram menor índice de dano por "umidade". Esses resultados estão de acordo com França-Neto et al. (2007), quando relataram que a deterioração por "umidade" ocorre após a maturidade fisiológica, antes, da semente ser colhida. Hamer (1999) relatou que a maturação em um campo de soja ocorre de forma extremamente desuniforme, com variação de até 15 dias entre a maturidade das primeiras plantas e a da maioria da população, quando se torna possível a realização da colheita. Essas plantas com maturação mais precoce normalmente são submetidas a altas variações da umidade relativa do ar, devido à ocorrência de chuvas no período ou pela variação natural da umidade relativa no decorrer do dia, o que pode provocar a redução na germinabilidade e principalmente no vigor das sementes. O mesmo autor explicou que essa é a causa da elevada ocorrência de danos por "umidade" detectados nos testes de tetrazólio em sementes produzidas no estado de Mato Grosso. A antecipação da colheita diminui o período de exposição das sementes às intempéries climáticas durante a fase de campo, reduzindo a incidência desses danos.

As sementes provenientes das dessecações com glifosato em plantas das cultivares Conquista, 2005/2006, e Tucunaré 2006/2007, no teste de comprimento de plântulas e da raiz primária, apresentaram valores inferiores aos das sementes oriundas dos outros tratamentos dessecantes, como também das testemunhas, sendo que os demais tratamentos não apresentaram diferenças entre si (Figura 7).

TABELA 3. Resultados médios de danos por "umidade" (classes 3 a 8), no teste de tetrazólio, referentes à interação “época de dessecação x época de colheita”, cultivar Tucunaré, safras 2005/2006 e 2006/2007.

* Dano por "Umidade" (\%)

\begin{tabular}{|c|c|c|c|c|c|c|}
\hline \multirow{3}{*}{ Dessecação } & \multicolumn{3}{|c|}{ 'Tucunaré' - 2005/2006 } & \multicolumn{2}{|c|}{ 'Tucunaré' - 2006/2007 } & \multirow{3}{*}{$\bar{X}$} \\
\hline & \multicolumn{2}{|c|}{ Colheita } & \multirow{2}{*}{$\bar{X}$} & \multicolumn{2}{|c|}{ Colheita } & \\
\hline & Antecipada & Normal & & Antecipada & Normal & \\
\hline R6.5 & $22,5 \mathrm{a} \mathrm{A}$ & $31,3 \mathrm{a} \mathrm{B}$ & 26,9 & $1,8 \mathrm{a} A$ & 4,0a B & 2,9 \\
\hline R7 & $19,9 \mathrm{a} \mathrm{A}$ & $32,4 \mathrm{a} \mathrm{B}$ & 26,2 & $2,5 \mathrm{a} \mathrm{A}$ & $4,8 \mathrm{a} \mathrm{B}$ & 3,7 \\
\hline $\bar{X}$ & 21,2 & 31,9 & 26,5 & 2,2 & 4,4 & 3,3 \\
\hline $\mathrm{CV}(\%)$ & \multicolumn{3}{|c|}{16,1} & \multicolumn{3}{|c|}{30,5} \\
\hline
\end{tabular}

Letras minúsculas comparam diferentes épocas de dessecação em cada período de armazenamento, e letras maiúsculas comparam cada época de dessecação entre os períodos de armazenamento. Médias seguidas de mesma letra não diferem entre si (Scott-Knott 5\%). *Dados originais, porém a análise estatística foi realizada com dados transformados para $\sqrt{ } \mathrm{x}+1$.

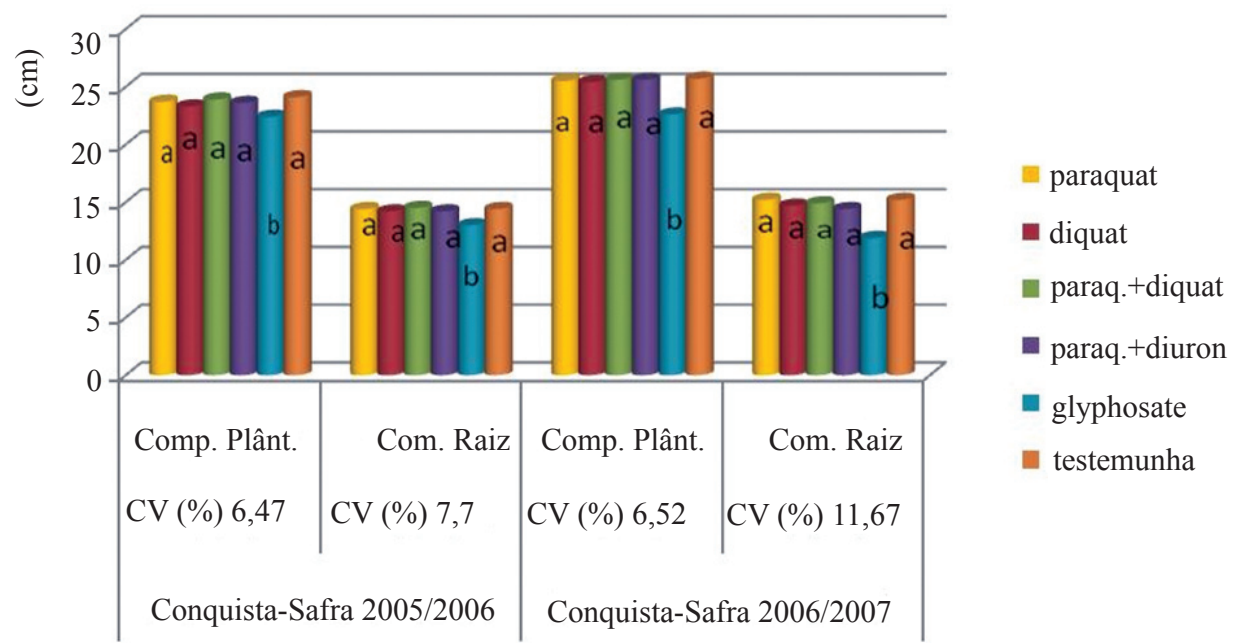

FIGURA 7. Resultados médios referentes ao comprimento de plântulas e da raiz primária, em sementes oriundas de plantas dessecadas e respectivas testemunhas, das cultivares Conquista, safra 2005/2006, e Tucunaré, safra 2006/2007. 
Também pelos resultados dos testes de comprimento de plântulas, comprimento do hipocótilo e comprimento da raiz primária, para as sementes de 'Tucunaré', safra 2005/2006, e de comprimento de plântulas e comprimento da raiz primária para 'Pintado', safra 2006/2007, referentes às épocas de colheita, verificou-se que a colheita antecipada proporcionou resultados superiores aos obtidos para a colheita normal, nos testes e cultivares considerados (Figura 8).

$\mathrm{Na}$ interação "produto x época de dessecação" (Tabela 4), apenas o tratamento com glifosato distinguiuse dos demais, na dessecação em R6.5, originando plântulas de menor comprimento nas análises das sementes da cultivar Conquista, 2005/2006, e de 'Tucunaré', 2006/2007. Esses resultados estão relacionados com o teor de água das sementes de soja no momento da dessecação da planta no estádio R6.5 em relação ao estádio R7, pois, além de ser um herbicida sistêmico, o glifosato tem a água como agente de transporte para os tecidos internos;quanto maior a quantidade de água existente em uma semente, maior a oportunidade do dessecante causar danos à semente (Miguel, 2003; Ferreira et al., 2007).
Ao contrário de Braccini et al. (2003), que não consideraram adequado o teste de comprimento de plântulas para a avaliação da qualidade fisiológica de sementes de soja, os resultados aqui apresentados, permitiram constatar que esse teste foi eficiente, permitindo distinguir diferenças e confirmar semelhanças nos diversos tratamentos avaliados. Resultados semelhantes foram obtidos por Vanzolini et al. (2007), em estudo sobre a determinação do vigor de lotes de sementes de soja, concluindo que o teste de comprimento de plântulas ou de suas partes é eficaz para detectar diferenças sutis de vigor.

De modo geral, os resultados de dois anos de pesquisa com o uso dos dessecantes paraquat, diquat, paraquat+diquat e paraquat+diuron, para produção de sementes de soja, não indicaram variações importantes no potencial fisiológico das sementes produzidas em relação às não dessecadas. Esses produtos provocaram efeitos semelhantes sobre o comportamento das sementes das diferentes cultivares, nos diversos testes realizados, também não diferindo das testemunhas. Esses resultados estão de acordo com os obtidos por Durigan (1980).

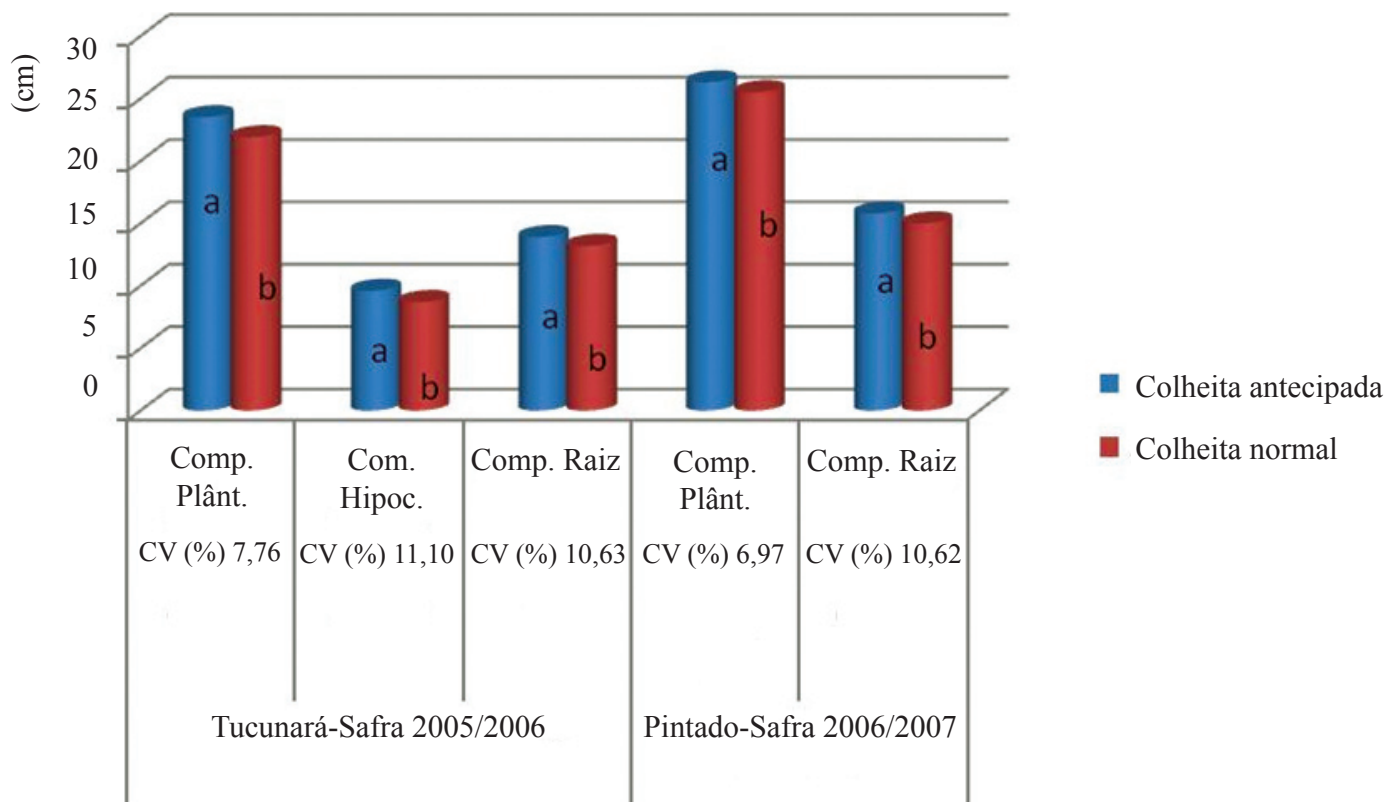

FIGURA 8. Resultados médios referentes ao comprimento de plântulas, do hipocótilo e da raiz primária, para a cultivar Tucunaré, safra 2005/2006, e de comprimento de plântulas e da raiz primária, para a cultivar Pintado, safra 2006/2007, nas colheitas antecipada e normal. 
TABELA 4. Resultados médios de comprimento de plântulas, referentes à interação "produto x época de dessecação", cultivares Conquista, safra 2005/2006 e Tucunaré, safra 2006/2007.

\begin{tabular}{|c|c|c|c|c|c|c|}
\hline \multicolumn{7}{|c|}{ Comprimento de Plântulas $(\mathrm{cm})$} \\
\hline \multirow{3}{*}{ Produto } & \multicolumn{3}{|c|}{ 'Conquista' - 2005/2006 } & \multicolumn{3}{|c|}{ ‘Tucunaré - 2007' - safra 2006/2007 } \\
\hline & \multicolumn{2}{|c|}{ Dessecação } & \multirow{2}{*}{$\bar{X}$} & \multicolumn{2}{|c|}{ Dessecação } & \multirow[b]{2}{*}{$\bar{X}$} \\
\hline & R6.5 & R7 & & R6.5 & $\mathrm{R} 7$ & \\
\hline Paraquat & 23,8 a $\mathrm{A}$ & $23,7 \mathrm{a} A$ & 23,8 & $25,9 \mathrm{a} \mathrm{A}$ & $25,2 \mathrm{a} \mathrm{A}$ & 25,6 \\
\hline Diquat & $23,6 \mathrm{a} A$ & $23,1 \mathrm{aA}$ & 23,4 & $25,2 \mathrm{a} \mathrm{A}$ & $25,7 \mathrm{a} A$ & 25,5 \\
\hline Paraquat+Diquat & $23,8 \mathrm{aA}$ & $23,9 \mathrm{a} A$ & 23,9 & $25,4 \mathrm{a} \mathrm{A}$ & $25,8 \mathrm{aA}$ & 25,6 \\
\hline Paraquat+Diuron & $23,9 \mathrm{a} \mathrm{A}$ & $23,2 \mathrm{a} \mathrm{A}$ & 23,6 & $25,8 \mathrm{a} \mathrm{A}$ & $25,4 \mathrm{a} \mathrm{A}$ & 25,6 \\
\hline Glifosato & $21,4 \mathrm{~b} \mathrm{~B}$ & $23,4 \mathrm{a} A$ & 22,4 & $20,1 \mathrm{~b} \mathrm{~B}$ & $25,0 \mathrm{a} A$ & 22,6 \\
\hline Testemunha & $24,1 \mathrm{a} \mathrm{A}$ & $24,1 \mathrm{a} \mathrm{A}$ & 24,1 & $25,7 \mathrm{a} A$ & $25,7 \mathrm{a} A$ & 25,7 \\
\hline $\bar{X}$ & 23,4 & 23,6 & 23,5 & 24,7 & 25,5 & 25,1 \\
\hline CV (\%) & & 6,5 & & & 6,5 & \\
\hline
\end{tabular}

Letras minúsculas comparam diferentes produtos em cada época de dessecação, e letras maiúsculas comparam cada produto entre as épocas de dessecação. Médias seguidas de mesma letra não diferem entre si (Scott-Knott 5\%).

Quanto ao herbicida glifosato, foi evidente sua ação negativa sobre o potencial fisiológico das sementes, em cultivares não portadoras do gene de resistência a esse produto. Os prejuízos ao desempenho das sementes, em especial o efeito fitotóxico, provocando sintomas característicos nas raízes das plântulas, foram observados nos experimentos conduzidos nas duas safras agrícolas.

Desse modo, os resultados desta pesquisa confirmam os danos causados às sementes de soja provenientes de plantas "convencionais" dessecadas em pré-colheita com glifosato, prática que está sendo difundida entre os produtores, após o advento da soja transgênica.

\section{CONCLUSÕES}

$\mathrm{O}$ uso dos dessecantes paraquat, diquat, paraquat+diquat $\mathrm{e}$ paraquat+diuron não afeta o rendimento e a qualidade fisiológica de sementes de soja, independente da época de aplicação.

Além de prejudicar o desempenho das sementes, o herbicida glifosato provoca fitotoxicidade ao sistema radicular de plântulas de soja, afetando negativamente a qualidade das sementes.

\section{REFERÊNCIAS}

BRACCINI, A.L.; MOTTA, I.S.; SCAPIM, C.A.; BRACCINI，M.C.L.; ÁVILA，M.R.; CHUAB， S.R. P. Semeadura da soja no período de safrinha: potencial fisiológico e sanidade das sementes. Revista Brasileira de Sementes, v.25, n.1, p.76-86, 2003.
BRASIL. Ministério da Agricultura e Reforma Agrária. Secretaria Nacional de Defesa Agropecuária. Departamento Nacional de Produção Vegetal. Coordenação de Laboratório Vegetal. Regras para análise de sementes. Brasília, DF, 1992. 365p.

CASEIRO, E.M.F.D.; CAMPELO JÚNIOR, J.H.; ALBUQUERQUE, M.C.F. Influência da época da colheita e do período de armazenamento na qualidade fisiológica das sementes de soja (Glycine max (L.) Merrill) de maturação precoce. Agricultura Tropical, v.3, n. 1, p. 48-60, 1997.

COSTA, N.P.; MESQUITA, C. M.; MAURINA, A.C.; FRANCA NETO, J.B.; KRZYZANOWSKI, F.C.; HENNING, A.A. Qualidade fisiológica, física e sanitária de sementes de soja produzidas no Brasil. Revista Brasileira de Sementes, v.25, n.1, p.128-132, 2003.

DE CASTRO, R.D.; BRADFORD, K.J.; HILHORST, H.W.M. Desenvolvimento de sementes e conteúdo de água. In: FERREIRA, A.G.; BORGHETTI, F. Germinação: do básico ao aplicado. Porto Alegre: Artmed, 2004. p.51-67.

DURE, L.I. Embryogenesis and gene expression during seed formation. Oxford Survey on Plant Molecular and Cell Biology, v.2, p.179-197, 1985.

DURIGAN, J.C.; CARVALHO, N.M. Aplicação, em précolheita, de dessecantes em duas cultivares de soja (Glycine $\max ($ L.) Merrill. I - Efeitos imediatos sobre a germinação e produção de sementes. Planta Daninha, v.3, n.1, p.108-115, 1980. 
FEHR, W.R.; CAVINESS, C.E. Stages of soybean development. Iowa Agricultural Experimental Station Special Report, v.80, p.1 - 11, 1977.

FERREIRA, A.C.B.; LAMAS, F.M.; PROCÓPIO, S.O. Sintomas de fitotoxidez de herbicidas no algodoeiro. Campina Grande: Embrapa Algodão. 2007.17p. (Circular Técnica 109)

FRANÇA NETO, J.B.; HENNING, A.A. Qualidade fisiológica e sanitária de sementes de soja. Londrina: Embrapa Soja , 1984. 39p. (Circular Técnica, 9).

FRANÇA NETO, J.B.; KRZYZANOWSKI, F.C. Dano de embebição - um problema comum no teste padrão de germinação de sementes de soja. Informativo ABRATES, v.3, n.2. p.10, 1993.

FRANÇA NETO, J.B.; KRZYZANOWSKI, F.C.; COSTA, N.P. O teste de tetrazólio em sementes de soja. Londrina: Embrapa Soja, 1998. 72p. (Documentos 116).

FRANÇA-NETO, J.B.; KRZYZANOWSKI, F.C.; PÁDUA, G.P.; COSTA, N.P.; HENNING, A.A. Tecnologia da produção de semente de soja de alta qualidade: Série Sementes. Londrina: Embrapa Soja. 2007. 12p. (Circular Técnica 40).

HAMER, E. Maturação de sementes de soja no trópico úmido. 1999. 58f. Tese (Doutorado em Ciência e Tecnologia de Sementes) - Universidade Federal de Pelotas, Pelotas, 1999.

KAPPES, C.; CARVALHO, M.A.C.; YAMASHITA, O.M. Potencial fisiológico de sementes de soja dessecadas com diquat e paraquat . Scientia Agraria, v.10, n.1, p.1-6, 2009.

LACERDA, A.L.S.; LAZARINI, E.; SÁ, M.E.; VALÉRIO FILHO, W.V. Armazenamento de sementes de soja dessecadas e avaliação da qualidade fisiológica, bioquímica e sanitária. Revista Brasileira de Sementes, v.25, n.2, p.97105, 2003.
LACERDA, A.L.S.; LAZARINI, E.; SÁ, M.E.; VALÉRIO FILHO, W.V. Efeitos da dessecação de plantas de soja no potencial fisiológico e sanitário das sementes. Bragantia, v. 64, n.3, p.447-457, 2005.

MARCOS FILHO, J. Fisiologia de sementes de plantas cultivadas. Piracicaba: FEALQ, 2005. 495p.

MIGUEL, M.H. Herbicidas dessecantes: momento de aplicação, eficiência e influência no rendimento e na qualidade de sementes de feijão. 2003.111f. Tese(Doutorado em Agronomia) - Escola Superior de Agricultura Luiz de Queiroz, Universidade de São Paulo, Piracicaba, 2003.

NAKAGAWA, J. Testes de vigor baseados no desempenho das plântulas. In: KRZYZANOWSKI, F.C.; VIEIRA, R.D.; FRANÇA-NETO, J.B. Vigor de sementes: conceitos e testes. Londrina: ABRATES, 1999, p.21-24.

PELÚZIO, J.M.; RAMO, L.N.; FIDELIS, R.R.; AFFÉRRI, F.S.; CASTRO-NETO, M.D.; CORREIA, M.A.R. Influência da dessecação química e retardamento de colheita na qualidade fisiológica de sementes de soja no sul do estado do Tocantins. Bioscience Journal, v.24, n.2, p.77-82, 2008.

PESKE, S.T.; HAMER, E.; Colheita de sementes de soja com alto grau de umidade. II - Qualidade fisiológica. Revista Brasileira de Sementes, v.19, n.1, p.66-70, 1997.

VANZOLINI, S.; ARAKI, C.A.S.; SILVA, A.C.T.M.; NAKAGAWA, J. Teste de comprimento de plântula na avaliação da qualidade fisiológica de sementes de soja. Revista Brasileira de Sementes, v.29, n.2, p.90-96, 2007.

VILLACORTA, H.S. Some effects of pre-harvest desiccation on soybean (Glycine max (L.) Merr.) seed quality. 1980. 95f. Thesis (Doctor of Philosophy) Department of Agronomy, Faculty of Mississippi State University, Mississippi, 1980. 